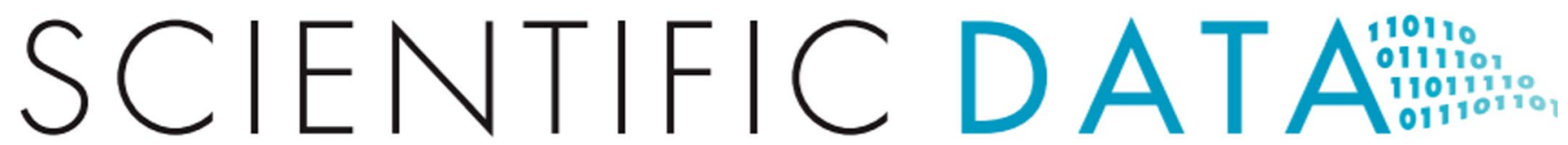

Published online: 17 February 2020

\title{
OPEN Author Correction: Physical and chemical descriptors for predicting interfacial thermal resistance
}

Yen-Ju Wu $\mathbb{D}$, Tianzhuo Zhan, Zhufeng Hou, Lei Fang \& Yibin Xu

Correction to: Scientific Data https://doi.org/10.1038/s41597-020-0373-2, published online 03 February 2020

Following publication of this Data Descriptor, it was found that references in the "Reference (id-R)" column of Table 1 that were intended to correspond to references in the ITR dataset.xlsx file of the accompanying dataset were incorrectly displayed as bibliographic references. Table 1 has been updated to make this distinction clear in both the HTML and PDF versions.

(c) Open Access This article is licensed under a Creative Commons Attribution 4.0 International License, which permits use, sharing, adaptation, distribution and reproduction in any medium or format, as long as you give appropriate credit to the original author(s) and the source, provide a link to the Creative Commons license, and indicate if changes were made. The images or other third party material in this article are included in the article's Creative Commons license, unless indicated otherwise in a credit line to the material. If material is not included in the article's Creative Commons license and your intended use is not permitted by statutory regulation or exceeds the permitted use, you will need to obtain permission directly from the copyright holder. To view a copy of this license, visit http://creativecommons.org/licenses/by/4.0/.

(C) The Author(s) 2020 